Z. Klin. Chem. Klin. Biochem.

11. Jg. 1973, S. $184-188$

\title{
A Simple, Kinetic Procedure for the Optimized Determination of the Activity of Serum Glutamate Dehydrogenase (EC 1.4.1.2.) with an Enzyme Analyzer
}

\author{
By R. HAeckel \\ Institut fïr Klinische Cbemie (Geschäftsfübrender Direktor: Prof. Dr. Dr. J. Büttner) \\ Medizinische Hochschule Hannover
}

(Eingegangen am 16. November/29. Dezember 1972)

The reliability of a mechanized procedure for the determination of the glutamate dehydrogenase activity in human sera was investigated with an Eppendorf analyzer 5011. In spite of a 1:3.5 ratio of sample to assay volume, carry-over effects can be neglected between serà containing less than $60 \mathrm{U} / 1$. For routine purposes it is suggested that $0.3 \mathrm{U} / \mathrm{l}$ be subtracted from each activity found in human sera and that individual blank values are not measured.

Die Zuverlässigkeit einer mechanisierten Bestimmung der Glutamatdehydrogenase-Aktivität in menschlichem Serum wurde mit einem Eppendorf-Automaten 5011 untersucht. Obwohl das Verhältnis von Probe- zu Ansatzvolumen 1:3,5 beträgt, können Verschleppungseffekte zwischen Seren, die weniger als $60 \mathrm{U} / \mathrm{l}$ enthalten, vernachlässigt werden. Für Routineuntersuchungen wird vorgeschlagen, auf die Bestimmung eines individuellen Probenleerwertes zu verzichten und $0,3 \mathrm{U} / 1$ als konstanten Betrag von der im menschlichen Serum gefundenen Aktivität abzuziehen.

The activity of serum glutamate dehydrogenase (EC 1.4.1.3) has become a valid biochemical parameter for the differential diagnosis of hepatic diseases $(1-3)$. For this purpose, the enzyme is determined routinely on a large scale at our hospital. Therefore, a mechanized procedure was evaluated for its reliability.

The activity of this enzyme was measured under "optimized" conditions according to Schmidr (4) and the recommendations of the German Society for Clinical Chemistry (5). This procedure includes the determination of a sample blank value. For purposes of simplification we have investigated whether this blank could be subtracted from the result as a fixed value.

\section{Materials and Methods}

Triethanolamine, NADH (Trisodium salt) and ADP were purchased from C. F. Boehringer (D-68 Mannheim), control sera from Merz and Dade (D-8 Munich), bovine albumin (purest) from Behringwerke AG (D-355 Marburg) and all other chemicals p. a. from E. Merck AG (D-61 Darmstadt).

\section{Solutions}

1. Triethanolamine buffer: $90 \mathrm{mmol} / \mathrm{l}$

16.7 triethanolamine (Boehringer No. 15325), $1.675 \mathrm{~g}$ disodiumethylenedinitriloacetate (Merck No. ${ }^{8418)}+$ bidist. $\mathrm{H}_{2} \mathrm{O}$ to $1000 \mathrm{ml}$. The $\mathrm{pH}$ value should be 8.0 , otherwise it must be adjusted. This solution can be stored at $4^{\circ} \mathrm{C}$ for some months.

\section{2-Oxoglutarate: $252 \mathrm{mmol} / 1$}

$3.682 \mathrm{~g}$ 2-oxoglutarate (Merck No. 5194) + bidest. $\mathrm{H}_{2} \mathrm{O}$ to $100 \mathrm{ml}$. This solution can be stored 4 weeks at $4^{\circ} \mathrm{C}$.

3. Ammonium acetate: $900 \mathrm{mmol} / \mathrm{l}$

$6.937 \mathrm{~g}$ ammonium acetate (Merck No. 1116) + bidist. $\mathrm{H}_{2} \mathrm{O}$ to

$100 \mathrm{ml}$. This solution is stable for several months at $4^{\circ} \mathrm{C}$.
4. Nicotinamide-adenine-dinucleotide, reduced: $14.4 \mathrm{mmol} / \mathrm{I}$ $51.1 \mathrm{mg} \mathrm{NADH}$ (Boehringer No. 15142) + bidist. $\mathrm{H}_{2} \mathrm{O}$ to $5 \mathrm{ml}$. This solution can be stored $24 \mathrm{~h}$ at $4^{\circ} \mathrm{C}$.

5. Adenosine diphosphate: $72 \mathrm{mmol} / 1$

$339.3 \mathrm{mg}$ ADP (Boehringer No. 15691) + bidist. $\mathrm{H}_{2} \mathrm{O}$ to $10 \mathrm{ml}$ (Stable for 1 week at $4^{\circ} \mathrm{C}$ ).

6. Reaction mixture:

$\begin{array}{lr}\text { Solution 1 } & 40 \mathrm{ml} \\ \text { Solution 3 } & 8 \mathrm{ml} \\ \text { Solution 4 } & 1 \mathrm{ml} \\ \text { Solution 5 } & 1 \mathrm{ml}\end{array}$

The reaction mixture should be prepared immediately before use; it can be stored for $6 \mathrm{~h}$ at $4^{\circ} \mathrm{C}$.

Assay'
Reaction mixture
Sample
Mix and incubate 15 min at $25^{\circ} \mathrm{C}$
Solution 2
Mix and record the reaction at $334 \mathrm{~nm}$

1) Automatic cuvette-positioning attachment. 
Fig. 1

The sequence of samples introduced into the Eppendorf enzyme automat 5011 for the determination of the glutamate dehydrogenase activity. The intersegment $B$ can be repeated as often as reqiured

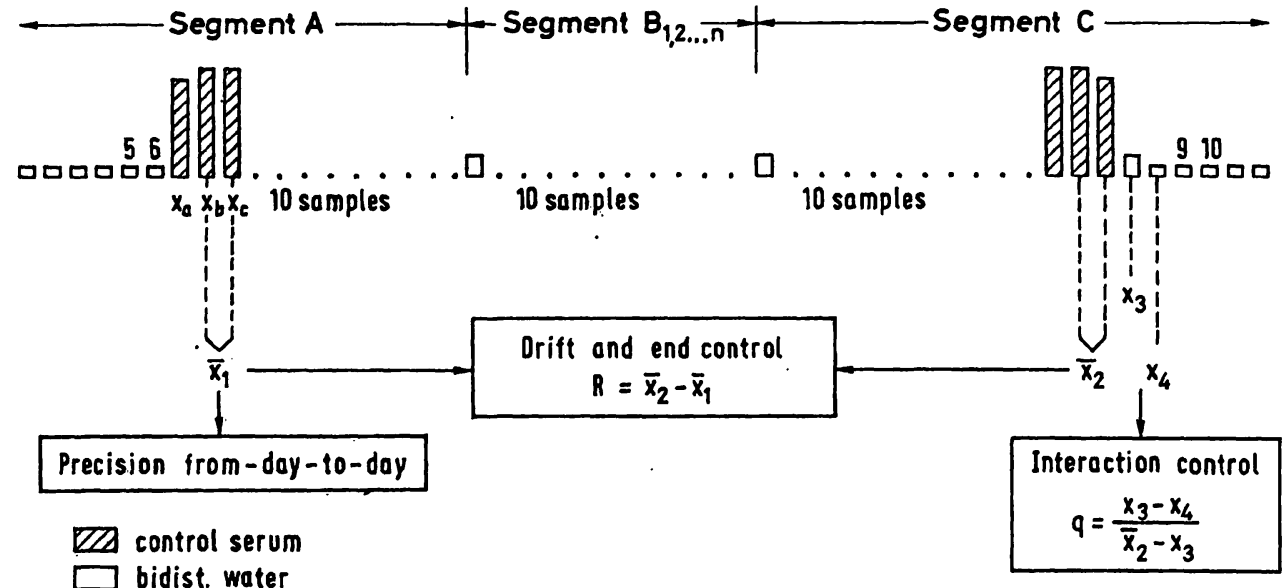

$$
\left(\bar{x}=\frac{\sum_{i=1}^{n}\left(x_{b 1}+x_{e t}\right)}{2 m} ; s=\sqrt{\frac{\sum_{i=1}^{n}\left(x_{b 1}-x_{C l}\right)^{2}}{2 m}}\right),
$$

the precision from-day-to-day from the $x_{b}-\left(\right.$ or the $x_{c}$ ) values

$$
\left(\bar{x}=\frac{\sum_{i=1}^{i=n} x_{b 1}}{n} ; s=\sqrt{\frac{\sum_{i=1}^{n}\left(x_{b i}-\bar{x}_{b}\right)^{2}}{n-1}}\right) .
$$

\section{Results and Discussion}

The procedure described above for the mechanized determination of the glutamate dehydrogenase activity in human serum samples is precise enough for clinical diagnostic purposes (Tab. 1). Under these experimental conditions an activity of up to $30 \mathrm{U} / \mathrm{l}$ can be measured and up to $60 \mathrm{U} / \mathrm{l}$ if the recorder paper runs at $2 \mathrm{~cm}$ per minute. Samples with higher activities must be diluted $1+4$. The detection limit was $0.3 \mathrm{U} / \mathrm{l} \quad(\overline{\mathrm{x}}=0.26$; $\mathrm{n}=4$ ).

The activity of the glutamate dehydrogenase was determined in serum samples from 97 patients by the automated and by a manual procedure. The data obtained with both methods show a good correlation (Fig. 2).

Since a relatively large sample volume is chosen, interaction effects have to be considered. The percent carry over from high to low activities $\left(Q_{2}\right)$ was $1.5 \pm 0.4$

Tab. 1

The precision of the mechanized determination of the glutamate dehydrogenase (GIDH) activity. Monitrol II (3 ml) was mixed with $50 \mu 1$ enzyme suspension containing various glutamate dehydrogenase (GIDH) activities as described under methods

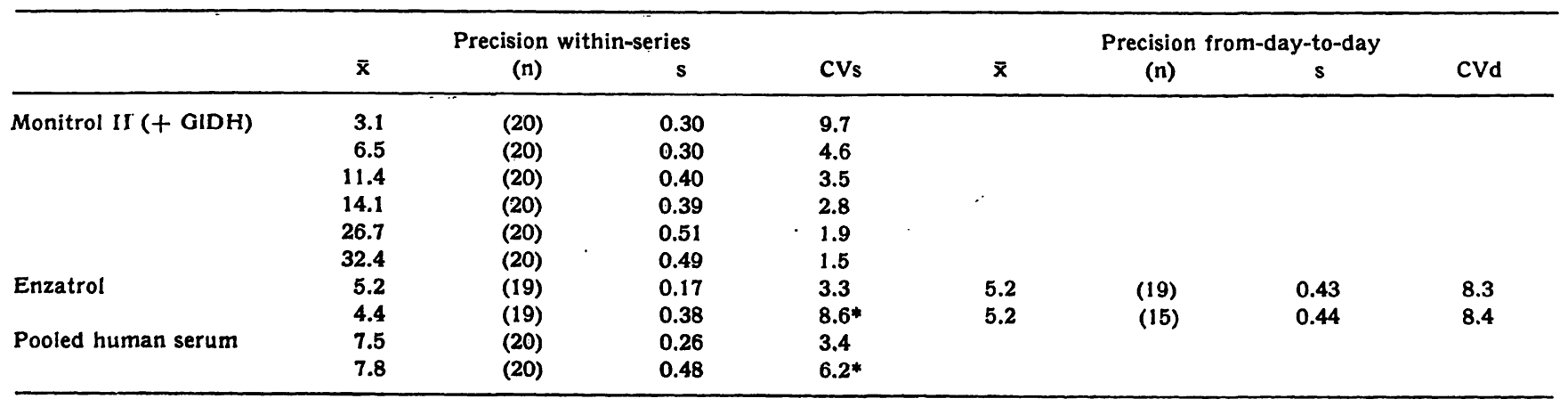

* $100 \mu 1$ sample $+500 \mu 1$ reaction mixture; end concentration of the assay according to 1. c. $(4,5)$ 


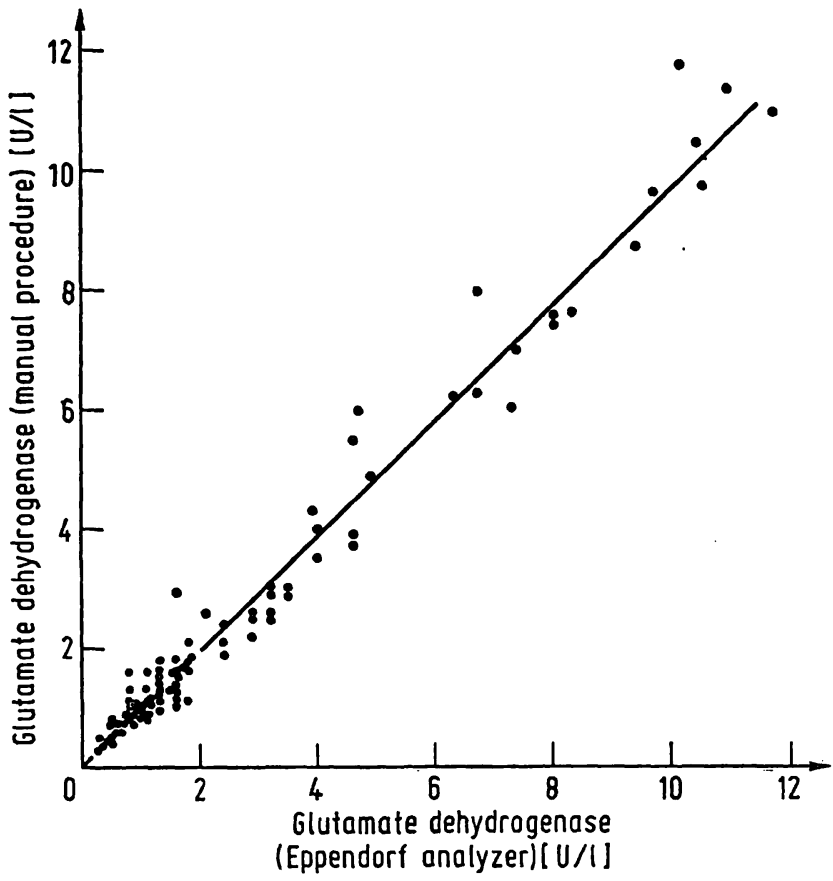

Fig. 2

Comparison of glutamate dehydrogenase activities in various serum samples determined with automated and a manual procedure: $y=0.9666 x+0.0444 ;$ coefficient of correlation $r=0.9942(n=97)$ i i

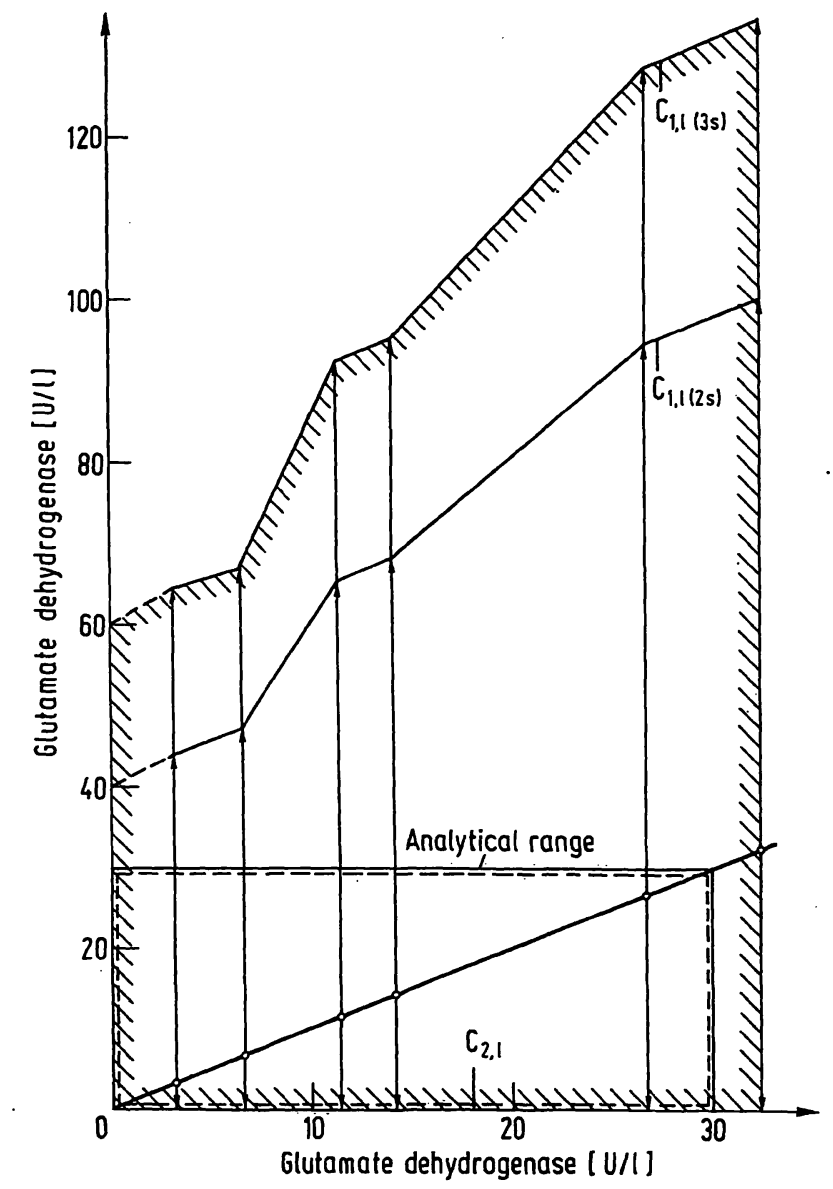

Fig. 3

The "interaction-safe range" (8) of the mechanized procedure for the determination of the glutamate dehydrogenase activity. The concentrations forming this range are calculated according to $1 . \mathrm{cc}$ (8): centrations forming this range are calculated according to $1 . C_{2}$. (8): the interaction from high to low concentrations. The standard deviations were taken from Table 1 . It is postulated that the error due value of the within-series precision (standard deviation)

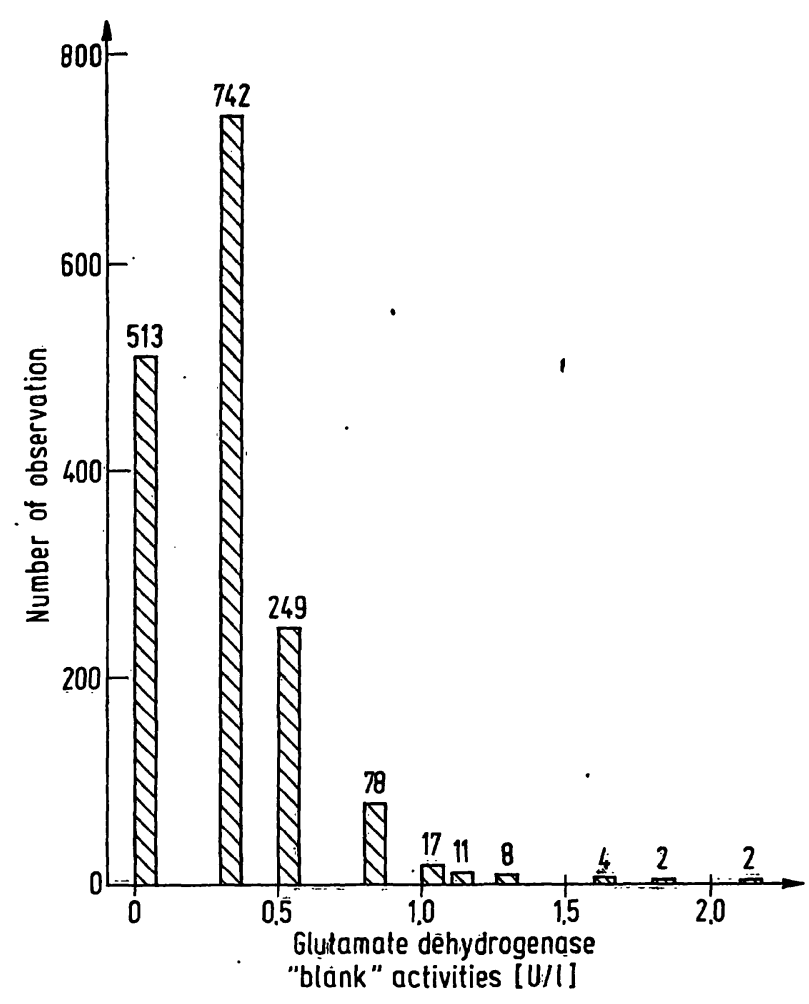

Fig. 4

The distribution of serum blank values in samples from 1626 patients. Bidist. $\mathrm{H}_{2} \mathrm{O}$ was substituted for 2 -oxoglutarate

determined on 10 different days, and could not be detected from low to high activities $\left(Q_{1}\right)$. Using a procedure recently developed (8), a so called "interaction-safe range" was calculated (Fig. 3) which demonstrated that carry over effects can be neglected between samples containing less than $60 \mathrm{U} / 1$. If a sample must be diluted because of its high activity, the analysis of the following sample must also be repeated.

In the test procedure proposed by SCHMIDT (4) an individual blank value has to be determined in which the substrate (2-oxoglutarate) is replaced by distilled water. The distribution of 1626 blank values from various patients shown in Figure 4 is not Gaussian. The median is at $0.3 \mathrm{U} / 1.93 \%$ of all values are not higher than 0.5 and $97 \%$ not higher than 0.8 .

For routine purposes we suggest that $0.3 \mathrm{U} / 1$ be subtracted from each activity found in human sera and that the determination of individual blank values be omitted. However, it must be determined whether the discrimination at the borderline between normal and patho-

Tab. 2

Activity values (U/I) which are estimated falsely above the normal range by the proposed procedure among 1616 unselected human sera

\begin{tabular}{cccc}
\hline Patient & $\begin{array}{c}\text { A } \\
\text { uncorrected } \\
\text { activity }\end{array}$ & $\begin{array}{c}\text { B } \\
\text { as, minus } \\
0.3\end{array}$ & $\begin{array}{c}\text { C } \\
\text { as A, minus } \\
\text { individual } \\
\text { blank value }\end{array}$ \\
\hline 1 & 4.0 & 3.7 & 1.9 \\
2 & 4.0 & 3.7 & 2.9 \\
3 & 3.5 & 3.2 & 1.9 \\
4 & 3.7 & 3.4 & 2.1 \\
\hline
\end{tabular}


Tab. 3

The influence of the sample volume on the glutamate dehydrogenase activity of various human sera. The volume of the reaction mixture (500 $\mu \mathrm{l})$ and the end concentrations of the assay (according to $1 . \mathrm{c}$. 5) were kept constant. $A=$ assay value, $B=$ sample blank value (bidist. $\mathrm{H}_{2} \mathrm{O}$ was substituted for 2-oxoglutarate), $C=A-B$. All figures are mean values (U/I) from 2 determinations

\begin{tabular}{|c|c|c|c|c|c|c|c|c|c|c|c|c|}
\hline $\begin{array}{l}\text { Sample } \\
\text { volume }\end{array}$ & & $50 \mu 1$ & & & $100 \mu 1$ & & & $200 \mu 1$ & & . & $300 \mu 1$ & \\
\hline No. & A & B & C & A & B & c & A & B & c & A & B & C \\
\hline 1 & 8.4 & 2.5 & 5.9 & 7.2 & 0.9 & 6.3 & 6.1 & 0.8 & 5.3 & 6.7 & 0.2 & 6.5 \\
\hline 2 & 4.1 & 1.3 & 2.8 & 4.5 & 0.7 & 3.8 & 3.4 & 0.8 & 2.6 & 3.4 & 0.2 & 3.2 \\
\hline 3 & 18.3 & 1.0 & 17.3 & 16.2 & 0.9 & 15.3 & 12.2 & $0.3^{\prime}$ & 11.9 & 13.3 & 0.3 & 13.0 \\
\hline 4 & 4.1 & 0.8 & 3.3 & 3.0 & 0.5 & 2.5 & 2.6 & 0.5 & 2.1 & 1.9 & 0.2 & 1.7 \\
\hline 5 & 7.6 & 1.3 & 7.3 & 5.3 & 0.9 & 4.4 & 4.0 & 0.3 & 3.7 & 3.6 & 0.2 & 3.4 \\
\hline 6 & 45.8 & 1.6 & 44.2 & 39.7 & 1.4 & 38.3 & 29.5 & 0.8 & 28.7 & 23.4 & 0.4 & 23.0 \\
\hline 7 & 26.9 & 1.3 & 25.3 & 23.7 & 0.9 & 22.8 & 18.2 & 0.4 & 17.8 & 18.0 & 0.3 & 17.7 \\
\hline 8 & 23.1 & 1.3 & $21: 8$ & 19.8 & 0.9 & 18.9 & 16.1 & 0.5 & 15.6 & 15.4 & 0.2 & 15.2 \\
\hline 9 & 29.1 & 1.3 & 27.8 & 27.3 & 0.9 & 26.4 & 21.9 & 0.8 & 21.1 & 21.7 & 0.5 & 21.2 \\
\hline$\overline{\mathbf{x}}$ & 18.6 & 1.3 & 17.3 & 16.3 & 0.9 & 15.4 & 12.7 & 0.6 & 12.1 & 11.9 & 0.3 & 11.6 \\
\hline
\end{tabular}

logical is not altered by the procedure just suggested. This borderline is at $3 \mathrm{U} / 1$ according to Schmidr (4). In 4 different sera out of 1626 the activity of glutamate dehydrogenase, calculated by subtracting 0.3 , was above $3 \mathrm{U} / \mathrm{l}$, whereas the results were below $3 \mathrm{U} / 1$ when the correct individual blank values were used (Tab. 2). Thus, the estimated activity of glutamate dehydrogenase was falsely above the normal range in $0.25 \%$ of all human sera checked during this investigation. In these cases, however, the error was too low to seriously mislead the physician. For scientific studies the individual blank values should further be considered.

Since a large serum volume is used for the glutamate dehydrogenase assay, the influence of sample volume on the enzyme activity was investigated. It was found with various sera that the glutamate dehydrogenase activity declines with increasing the sample volume (Tab. 3). This indicated that the proposed assay conditions are not optimal for serum samples. ScHмIDT (4) uses a 1:3.5 ratio between the volumes of the sample and the reaction mixture. If this ratio is changed to $1: 6$ and the end concentrations of the assay kept identical according to 1 . c. (5) the variation within series batch increased significantly (Tab. 1). Because of this result we suggest that the recommendation of ScHMrDT (4) be followed. This appears to be a reasonable com- promise for routine analytical purposes. The sample blank value was also lowered if the serum volume was increased (Tab. 3). The significance of this effect, which could be caused by an inhibitor of the side reaction present in human serum, requires further investigation.

Further experiments were performed to investigate whether sera diluted with various solutions have higher activities than undiluted samples. Serum samples

Tab. 4

The activity of the glutamate dehydrogenase in undiluted (A) and serum sample diluted $1+2$ with $0.9 \% \mathrm{NaCl}$ (B), Qualtrol (C) and albumine solution $(70 \mathrm{~g} / \mathrm{l}, \mathrm{D})$. All values $(\mathrm{U} / \mathrm{l})$ are means from 2 determinations

\begin{tabular}{rrrrr}
\hline $\begin{array}{c}\text { Patient } \\
\text { No. }\end{array}$ & A & B & C & . D \\
\hline 1 & 26.8 & 29.4 & 28.2 & 31.8 \\
2 & 26.8 & 28.2 & 26.1 & 28.2 \\
3 & 30.0 & 34.2 & 31.8 & 35.7 \\
4 & 16.4 & 17.4 & 17.4 & 19.2 \\
5 & 15.5 & 13.8 & 12.0 & 16.5 \\
6 & 25.7 & 24.0 & 21.9 & 27.3 \\
7 & 22.8 & 27.3 & 23.4 & 30.6 \\
8 & 8.0 & 11.1 & 8.7 & 9.6 \\
9 & 24.7 & 24.0 & 23.1 & 27.8 \\
10 & 13.5 & 13.8 & 11.2 & 14.7 \\
\hline mean & 21.0 & 22.4 & 20.4 & 24.1 \\
\hline
\end{tabular}

Tab. 5

The stability of the glutamate dehydrogenase activity in Enzatrol (Lot. No. ET 233 A) and humari sera if stored at room temperature (A) and at $4^{\circ} \mathrm{C}(\mathrm{B})$

\begin{tabular}{|c|c|c|c|c|c|c|c|c|c|}
\hline \multicolumn{2}{|c|}{$\begin{array}{l}\text { Time of } \\
\text { storage }\end{array}$} & \multicolumn{2}{|l|}{$2 \mathrm{~h}$} & $5 \mathrm{~h}$ & $24 \mathrm{~h}$ & $48 h$ & 5 days & \multicolumn{2}{|l|}{10 days } \\
\hline Enzatrol* & $\cdot A$ & $5.6 \pm 0.2$ & & $5.2 \pm 0.3$ & $4.6 \pm 0.4$ & $4.2 \pm 0.4$ & $4.0 * *$ & $3.4 * *$ & \\
\hline & B & $5.8 \pm 0.2$ & . & $5.5 \pm 0.3$ & $5.2 \pm 0.3$ & $4.8 \pm 0.2$ & $4.6^{* *}$ & $4.1 * *$ & \\
\hline Pat. 1 & B & 7.2 & & 7.2 & 7.2 & 7.3 & 7.2 & - & - \\
\hline Pat. 2 & B & 11.4 & & 11.8 & 12.9 & - & 12.5 & - & \\
\hline Pat. 3 & $\mathbf{A}$ & 19.9 & & 19.2 & 19.2 & 19.1 & 19.0 & - & \\
\hline & B & 19.9 & & 19.9 & 19.9 & 19.8 & 19.8 & - & \\
\hline Pat. 4 & $\mathbf{A}$ & 7.0 & & 7.0 & 6.7 & 6.4 & 6.0 & - & \\
\hline . & B & 7.3 & & 7.3 & 7.0 & 6.8 & 6.5 & - & \\
\hline Pat. 5 & $\mathbf{A}$ & 30.8 & & - & 28.2 & 28.2 & 28.2 & 17.0 & \\
\hline & B & 30.8 & & - & 29.5 & 29.5 & 29.4 & 23.7 & \\
\hline Pat. 6 & $\mathbf{A}$ & 12.6 & & - & 12.2 & 11.9 & 10.9 & 6.7 & \\
\hline & B & 13.5 & . & - & 12.7 & 12.5 & 11.7 & 9.8 & \\
\hline
\end{tabular}

* mean values from 7 (with standard deviation) and ** from 2 experiments 
from 10 different patients were diluted $1+2$ with $0.9 \% \mathrm{NaCl}$, Qualtrol and albumin solution. The glutamate dehydrogenase activity "Ir was determined in these preparations and in undiluted samples. The results compared in Table 4 indicate that Qualtrol is suitable for the dilution of serum samples with glutamate dehydrogenase activities above $30 \mathrm{U} / \mathrm{l}$. Both Qualtrol and the albumin solution contained no detectable activity of glutamate dehydrogenase.
Serum should be stored no longer than 5 days at $4^{\circ} \mathrm{C}$ before the glutamate dehydrogenase activity is measured (Tab. 5). At the present time, Enzatrol is the only commercial available serum which is suitable for the quality control of the glutamate dehydrogenase determination. However, the activity of this enzyme declines constantly, especially during the first hours (Tab. 5). Therefore, we use Enzatrol for the control of precision $24 \mathrm{~h}$ after its reconstitution.

\section{References}

1. Schmidt, E. \& Schmidt, F. W. (1968), Deut. Med. Wochenschr. 93, 1153-1155. - 2. Wahls, E. \& ARndt-Hauser, A. (1968), Arztl. Lab. 14, 397-407. - 3. Schмrdr, E. \& Scнмrdт, F. W. (1969), Schweiz. Med. Wochenschr. 99, 514-521. 4. SChuidt, E. (1970), in: H. U. BergmeYer Methoden der enzymatischen Analyse, Verlag Chemie, Weinheim 2, Aufl., 607-613. - 5. Standardisierung von Methoden zur Bestimmung von Enzymaktivitäten in biologischen Flüssigkeiten (1972), this j. 10, 182-192. - 6. HAECKEL, R. (1972), this j. 10, 235-242. - 7. Kaiser, H. (1965), Z. Analyt. Chemie 209, 1-18. - 8. HAeCKel, R. \& Porth, A. J. (1972), this j. 10, 91-94. - 9. Haeckel, R. \& HaEckel, H. (1972), in Fortschritte der Klinischen Chemie, Enzyme und Hormone (Karser, E., ed.), Verlag der Wiener Medizinischen Akademie, Wien, 115-119.

Priv.-Doz. Dr. R. Haeckel 3000 Hannover Karl-Wiechert-Allee 9 